\title{
TV/Series
}

$2 \mid 2012$

Les séries télévisées dans le monde : Échanges, déplacements et transpositions

\section{Dystopian Villages: Surveillance and Re-mediation in The Prisoner}

\section{Sébastien Lefait}

\section{CpenEdition}

\section{Journals}

Electronic version

URL: http://journals.openedition.org/tvseries/1394

DOI: 10.4000/tvseries.1394

ISSN: 2266-0909

Publisher

GRIC - Groupe de recherche Identités et Cultures

Electronic reference

Sébastien Lefait, "Dystopian Villages: Surveillance and Re-mediation in The Prisoner », TV/Series

[Online], 2 | 2012, Online since 01 November 2012, connection on 22 April 2019. URL : http://

journals.openedition.org/tvseries/1394; DOI : 10.4000/tvseries.1394

\section{(c) (i) (9)}

TV/Series est mis à disposition selon les termes de la licence Creative Commons Attribution - Pas d'Utilisation Commerciale - Pas de Modification 4.0 International. 


\title{
Dystopian Villages: \\ Surveillance and Re-mediation in The Prisoner ${ }^{1}$
}

\begin{abstract}
The 2009 Prisoner is an adaptation rather than a remake, as many changes from the original may be noticed. One of the most important adjustments is related to the use of surveillance in the creation of a dystopic society. The original series' space, which was entirely submitted to Number 2's gaze, could be defined as panoptic, an aspect of the show designed to expose the upcoming or possible evils of what would later be called the surveillance society. The 1967 Prisoner, however, mainly showed surveillance to be an instrument of power, even if the watchers' gaze was sometimes equated with the spectators', thereby proving TV to bring a different form of power, based on showing as much as on watching. An iconic change in the new version is that the 2009 Prisoner resigned from a New York-based surveillance company called Summakor, whereas his 1967 counterpart was a British government agent. This seemingly incidental relocation gives new meaning to the TV series as a whole, as surveillance, which was one of the prominent themes of the original programme, becomes a keystone of the whole plot in the 2009 Prisoner. The new series goes much further in investigating the media-related aspects of the surveillance society as well as the social and ideological changes prompted by the creation of new forms of surveillance technology (which have made panopticism a concept to be reassessed or even renewed). The aim of this paper is to show that the 2009 Prisoner manages to adapt the dimension of social criticism of the 1967 Village - the gilded cage the prisoner is sent to - by turning it into another form of dystopia, which takes into account the heightened importance of surveillance in contemporary society, as well as the major changes in the meaning and purposes of surveillance brought about by new technology.
\end{abstract}

$\mathrm{I}$

$\mathrm{n}$ the wake of FOX channel's 24 (2001-10), a trend, increasingly noticeable in cinema since the 1980 , has been perceptibly infiltrating TV series. The trend is visible as the common factor appearing in widely varying programmes such as Lost (ABC, 20042010) and The Wire (HBO, 2002-2008). What these series have in common is their extensive use of surveillance, either as the very concept for the series or on a seasonal scale ${ }^{2}$. To this shortlist, numerous surveillance episodes in such dissimilar programmes as Law \& Order: Special Victims Unit (NBC, 1999-), The Office (NBC, 2005-) or The Simpsons (Fox, 1987-) should be added3. To account for such a widespread phenomenon requires more than the "reflection-of-society" perspective $^{4}$ that is so often applied to cinema and seems even more

${ }^{1}$ The 1967 and 2009 versions.

${ }^{2}$ Season 3 in Lost being the most surveillance related, although the notion applies to the series as a whole if surveillance narrative techniques are considered.

${ }^{3}$ Law \& Order: Special Victims Unit season 3 episode 17 is entitled "Surveillance"; The Office (U.S. version) season 2 episode 9 is entitled "E-Mail Surveillance" and The Simpsons season 21 episode 20 is "To Surveil, With Love". Apart from this very limited sample, many episode plots in other series feature surveillance without their title illustrating the fact. The whole span of TV series is virtually covered by the spread of surveillance, even more so since such programmes as Big Brother are considered to be series, their segmentation into seasons and episodes inviting us to do so.

4 "The dominant theoretical orientation of most sociological and historical studies of film genres and cycles is the reflection-of-society perspective. According to this viewpoint, shifts 
fitted to television programmes. In fact, as Jane Feuer argues, "just as TV images could not be said to have caused the eighties, neither could the eighties be said to have produced the images as a simple reflection of the times5." In a similar vein, I propose to explore, over a wider period, why the trend of surveillance came about and how it affects TV series.

The tendency can be traced back to one of contemporary TV series' arch ancestors, Patrick McGoohan's The Prisoner (ATV, 19671968), whose exploitation of surveillance actually leads to an alternative explanation. As the extensive use of surveillance devices in the public space can be dated to the 1980s, with a sharp increase in the 1990s, the original Prisoner can hardly be said to illustrate changes massively occurring in the society of its time, let alone affecting audience tastes. In the series, the Village to which the main character is sent is an imaginary location which can obviously be interpreted as a dystopian allegory or a projection of 1967 Europe, but not as a description of a particular place.

As a result, the 1967 Prisoner's use of surveillance, rather than being descriptive, takes its originality from its inscriptive quality: surveillance fits in the narrative pattern of the series while, at the same time, TV is shown to play a part in the surveillance system the plot presents. In this renowned series, then, surveillance is not treated passively as a theme, but functions dynamically as a narrative and reflexive agent. The first moments of episode 3, entitled "Free for all", exemplify this two-way inscriptive process. At the very beginning of the episode, The Prisoner's credits sequence shows a British spy suddenly resigning and driving home in his sports car, followed by a hearse. Once at home, he packs up, presumably to go on holidays, and the undertaker formerly driving the hearse pours anaesthetic gases into the room. When he wakes up, the British agent looks out the window and realises he is now in a strange place that, as he learns in the first episode, is called the Village. The sequence that comes next is used in all but four of the Prisoner episodes. It describes the Village as a surveillance microcosm through the use of high-angle shots which could be taken from spying cameras towering over the place (see Plate 1).

in film content reflect changes in audience taste preferences which are, in turn, linked to major shifts in the structure of society.” Robert E. Kapsis, Hitchcock: The Making of a Reputation, Chicago, University of Chicago Press, 1992, p. 3.

5 Jane Feuer, Seeing Through the Eighties: Television and Reaganism, Durham, Duke University Press, 1995, p. 2. 


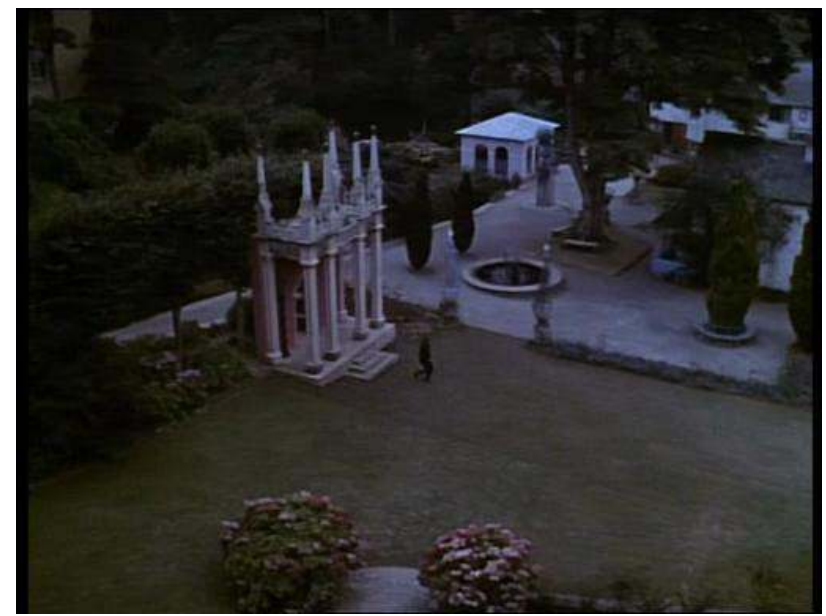

Plate 1

Such shots seem to indicate that what the spectators are given to see is captured by a camera belonging to the diegetic world, so that they could be described, if we consider surveillance as a form of ocularisation and adapt Gaudreault and Jost's terminology, as primary surveillance shots ${ }^{6}$. However, by casting a closer look at the first few shots in the sequence and by taking the next pictures into consideration, we are led to qualify such an interpretation. The first overall view of the Village, when the episode title appears, may be fixed, but the second high angle shot pans right to follow "Number 6" the name ascribed to the British spy by the inhabitants of the Village. If those shots are taken by a diegetic surveillance camera, it is necessarily one that is able to move from left to right around a central axis. The sequence then includes another high-angle shot of Number 6 running on a deserted beach, which contains a zooming effect. Then come a low-angle shot of the character's mad race and another high-angle shot of the same continued action, in which the camera now tracks from

\footnotetext{
6 “[Dans le cas de l'ocularisation interne primaire,] il s'agit [...] de suggérer le regard, sans forcément le montrer ; pour ce faire, on construit l'image comme un indice, comme une trace qui permet au spectateur d'établir un lien immédiat entre ce qu'il voit et l'instrument de prise de vues qui a capté ou reproduit le réel, par la construction d'une analogie avec sa propre perception." "[With primary internal ocularisation], the fact that a character is watching what is shown on screen is suggested rather than directly shown. To that effect, the picture is structured as a clue or trace which allows the spectators to immediately connect what they are seeing with the reality-capturing instrument which has shot or reproduced the real world, through the construction of an analogy with their own perception.” André Gaudreault and François Jost, Le Récit cinématographique, Paris, Nathan, 1990, p. 131, my translation. Similarly, a primary surveillance shot bears the trace that what is reproduced on screen was captured by a diegetic surveillance camera.
} 
right to left. Those are followed by closer shots of the Rover, the famous balloon whose role is to chase after escapees.

As this brief description indicates, the sequence almost imperceptibly shifts from shots which can consistently be interpreted to be taken by surveillance cameras to a more classically cinematic shooting style. In fact, if it is possible to imagine a surveillance camera with the ability to pan or zoom, it is far less likely for a surveillance camera to be able to track laterally. This first series of shots, however, is undoubtedly described as a case of Number 2 watching Number 6 through reality capturing-devices. Number 2 (the ruler of the place) appears twice in the next part of the sequence, first in a medium closeup shot, then, immediately after, in a reverse shot that situates him in the Village control room, sitting in a ball shaped armchair in front of a large screen displaying images of the Rover now actually in pursuit of the Prisoner (see Plate 2).

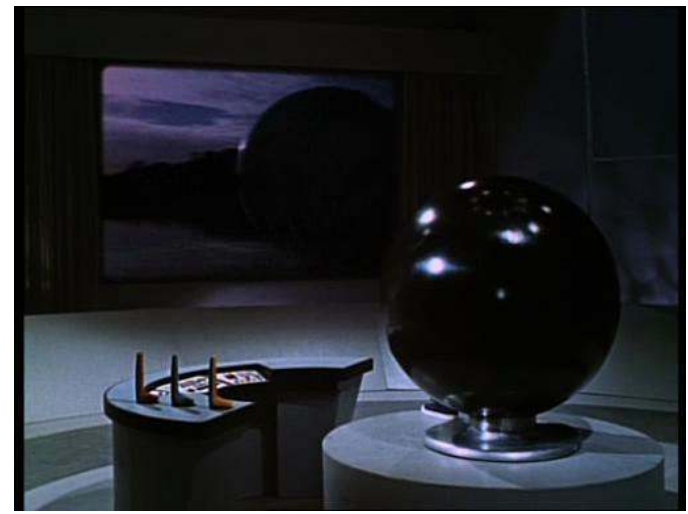

Plate 2

To use ocularisation terminology again, the images on the screen within the screen are secondary surveillance shots7, because they are edited next to a shot of the watcher in the control room.

\footnotetext{
7 “[Dans le cas de l'ocularisation interne secondaire,] la subjectivité de l'image est construite par les raccords (comme dans le champ-contrechamp), par une contextualisation. N'importe quelle image qui raccorde avec un regard montré à l'écran, à condition que quelques règles 'syntaxiques' soient respectées, sera ancrée dans celui-ci." "[Secondary internal ocularisation] takes its specificity from the fact that a shot becomes subjective through continuity with another shot (as for example in a shot-reverse shot sequence), i.e. through contextualisation. Any shot introduced immediately after the shot of someone watching, provided certain 'syntactic' rules are abided by, becomes part of what they are watching." Gaudreault and Jost, p. 133 (my translation). Similarly, a secondary surveillance shot is contextualised as such through editing, for instance when the shot of a CCTV camera is inserted before a static high angle shot of the inside of a room.
} 
Given this construction of the credits sequence as surveillance footage, it is easy to forget that it intermingles two types of shots some of which can be read to have been taken by diegetic surveillance cameras; some of which, however, clearly show the actors ignoring the presence of the camera, a case in point being the view of Number 6 rushing to the foreground with the Rover close on his heels. The sequence Number 2 is watching in order to "watch" Number 6 , then, is fictional footage shot in the style of surveillance rather than actual surveillance recording. The feeling thus conveyed is that Number 2 has found the perfect way of keeping Number 6 under his gaze, wherever and whenever he goes, by lackadaisically watching the series, comfortably settled in his armchair, the way its spectators in the real world do. The mise-en-abyme is further encouraged by the fact that Number 2's globe-shaped armchair is shot from behind to recall the form of the chasing balloon: it is as if the Rover were both on the side of the watcher and on the side of the watched (see Plate 2).

The opening of the "Free for all" episode is specific in that it extends the scopic regime of the credits sequence to the beginning of the episode per se. As the plot begins to unravel, the two-way screen presented at the end of the credits sequence, which displays TV pictures but is sometimes treated as transparent, is found again in a slightly different form. Number 2 imposes his visit upon Number 6 through a phone call soon to be supplemented by shots of the character with the receiver in his hand, displayed on a screen in Number 6's house (see Plate 3).

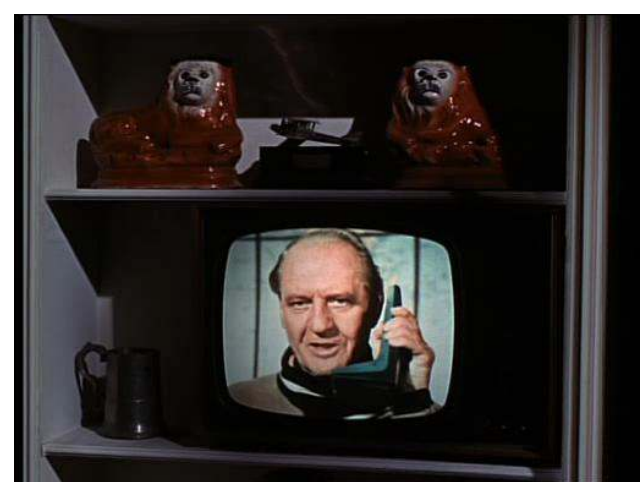

Plate 3

This variation on the telescreens featured in George Orwell's Nineteen Eighty-Four (1949), which serve both as showing and watching instruments, is however complete with a new feature: the telescreen has obviously become a television screen. Number 2 then appears at the door, with an umbrella rather than a receiver in his hand, which 
suggests that the telescreen is not a mere video door intercom. Rather, the construction of the sequence suggests that Number 2 is simultaneously behind the door and on the screen - i.e. in two different places at the same time - because the sequence on the screen has been rehearsed and put on, very much like a TV show. This, however, is contradicted by the fact that Number 2's picture on the screen is able to answer Number 6's questions, which presents the television glass as transparent. The device is thus depicted as enabling both actors and viewers to simultaneously watch and be watched, an imaginary hypothesis which may seem totally preposterous unless one considers that Number 6's questions are no more improvised than Number 2's replies. In fact, part of the script is spoken through the diegetic TV screen, which is therefore treated as a window looking into a fictional world. The ultimate surveillance device imagined by Orwell is translated into the most common domestic appliance; television is represented as an instrument of control, in a double equation between watching TV and surveilling on the one hand, watching TV and being surveilled on the other hand.

As this sequence shows, in the original version of The Prisoner, the Village is a kind of gilded cage with no bars, a prison from which it is impossible to go away due to an elaborate surveillance system enabling the powers that be to immediately detect escape attempts. The series' space, circumscribed as it is to what cameras can see, is entirely submitted to Number 2's gaze, so that it can be defined as panoptic, because the ubiquitous watching of the whole place is centralized in one character, thus enabling, in keeping with David Lyon's definition of panoptic devices, "the few to watch the many" This aspect of the show may be thought to expose, through the nightmarish vision of the Village's surveillance dystopia, the upcoming or virtual evils of what would later be called the "surveillance society".

The 1967 Prisoner, however, does not merely present surveillance as an instrument of power, but derives its specificity from the role it ascribes to television in the surveillance pattern it describes. By equating the watchers' gaze with that of the spectators, the show offers a reflection on the nascent surveillance society rather than a mere reflection of the society of its time. In a visionary move, it reflectively includes TV in a hypothetical surveillance system, thus suggesting that showing devices can be used as surveillance tools. This groundbreaking idea at the time has, by now, become quite commonplace in the field of surveillance studies via the concept of the synopticon coined by Thomas Mathiesen to characterize surveillance through and in the mass media, and described by Lyon as enabling "the

${ }^{8}$ David Lyon, Surveillance Studies: An Overview, Cambridge, UK, Polity, 2007, p. 204. 
many to watch the few ${ }^{9}$. One of the possible implications of the concept is that the mass media, by teaching billions of viewers how to watch, may act as instruments of control, an aspect merely suggested in the 1967 Prisoner, but explored in depth in the 2009 version of The Prisoner (AMC, 2009), written by Bill Gallagher and directed by Nick Hurran.

The new Prisoner should be considered to be an adaptation rather than a remake especially because of the new role it grants surveillance in the creation of a dystopian society. For instance, while the 1967 Prisoner was a British government agent who had just resigned, his 2009 counterpart, Michael, a.k.a. Number 6 in the Village, quit a New York-based surveillance company called Summakor. This seemingly incidental relocation gives new meaning to the TV series as a whole, as surveillance, which was one of the prominent themes of the original programme, becomes the keystone of the plot in the 2009 version. Just as in the original series, the plot introduces Michael as he wakes up in a strange place, the Village, where everyone is assigned a number instead of a name. He is then called " 6 ", and proceeds to find out where he is, which involves, just as in the original plot, constant fighting for freedom with Number 2. The key to the story, however, is a major innovation: unlike the first version, the 2009 Prisoner ends with a revelation concerning the nature of the Village, rather than the identity of the mysterious Number 1. The new Prisoner thus goes much further in investigating the media-related aspects of the surveillance society, as well as the social and ideological changes prompted by the creation of new forms of surveillance technology, which have made panopticism a concept to be reassessed or even renewed. The aim of the second part of this paper is to show that the 2009 Prisoner manages to adapt the dimension of surveillance warning of the 1967 Village by turning it into another form of surveillance dystopia, thus taking into account the heightened importance of surveillance in contemporary society, as well as the major changes in the meaning and purposes of surveillance brought about by new technologies ${ }^{10}$.

On the first viewing, however, the 2009 version of The Prisoner may seem to construct the same equation between TV screen and control screen as the original. In the second episode, Number 6's supposed brother, Number 16 , takes him on a bus tour into the desert, during which 6 spots signs that there may be a world outside the Village. Among those clues is an abandoned train station where, 16

9 Ibid. The reference is to Thomas Mathiesen, "The Viewer Society: Michel Foucault's 'Panopticon' Revisited”, Theoretical Criminology, Vol. 1, No. 2, 1997, p. 215-234.

10 The existence of a link to a fake Summakor website on the series' official page also provides convincing evidence of its creators' wish to anchor the series in the reality of contemporary surveillance societies: http://www.summakor.com (consulted June $27^{\text {th }}$, 2011). 
claims, they used to play when they were children. The sequence of their visit to the station, which 16 calls "the edge of the world", includes a shot that is slightly different from the others, as it is taken from further away and preceded by what sounds like the noise of channelhopping or switching to a different camera on a control screen; those changes are complemented with an alteration of the soundtrack, which makes the characters' voices sound as if they were captured by a distant microphone (see Plates 4 and 5).
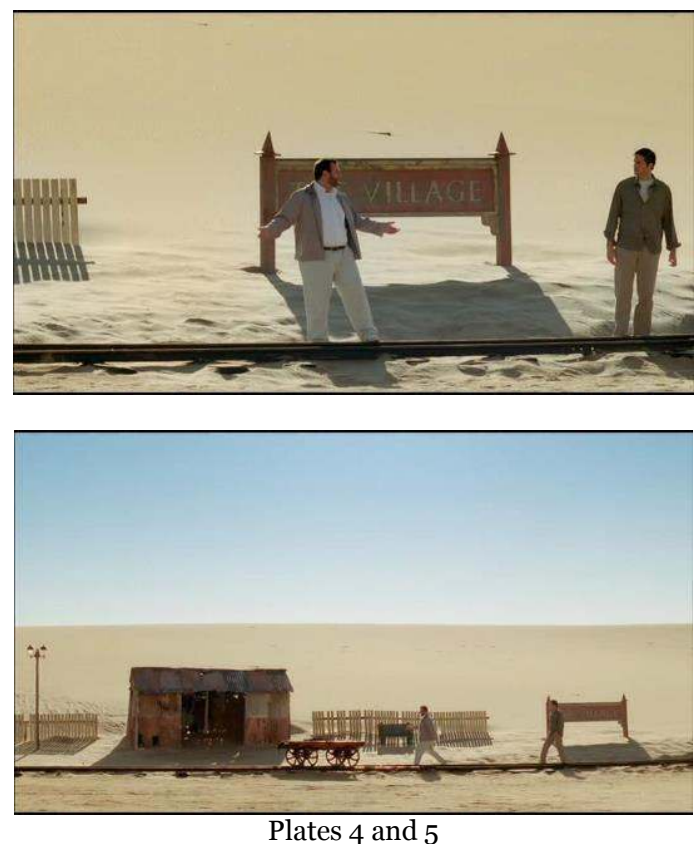

The series includes many shots of this type, which bear the stamp of surveillance, and naturally place the spectators in the position of watchmen. But even though such shots create the same confusion between watching the show and watching a surveillance screen as the original Prisoner, the 2009 version takes the device to a whole new level. By resorting mostly to primary surveillance shots, as is the case in the deserted train station sequence, the show depicts watching TV as a form of surveillance without one-sidedly presenting a character to be holding the central gaze, thus leaving the seat in front of the control screen vacant for the spectator to occupy.

This more radical treatment of an aspect present in the original show does not entail, however, that Number 2's panoptic control over 
the Village has totally disappeared from the new version, as a short sequence at the end of episode 3 demonstrates. Because he is concerned about his gay son's taste for the Village's nightlife, Number 2 keeps him under close scrutiny by watching him on his laptop computer. The pictures of his son displayed on 2's screen are the same as those shown on the spectators' TV set, so that Number 2 seems to be watching the series in order to keep watch over the Villagers. It may seem at first that this sequence merely updates a similar one in the original show by acknowledging that TV series may now be watched on computer screens rather than on actual television sets. Such a reading would be consistent if television sets were not in use in the Village - yet they are. However, even though TV appliances are watched by the Villagers, they seem to have lost their watching power with the invention of more sophisticated surveillance devices, or at least to be now used within a different surveillance scheme, as a sequence in episode 2 suggests. In this sequence, loudspeakers scattered around the Village call for its inhabitants to gather in front of their TV screen to watch a soap opera called "Wonkers", a show they "never miss", as Number 16's wife comments. The sequence is characterised by shots from above (see Plate 6), presented as taken from the same kind of towering location where the loudspeakers are placed, chiefly because of the lowered level of the character's voices.

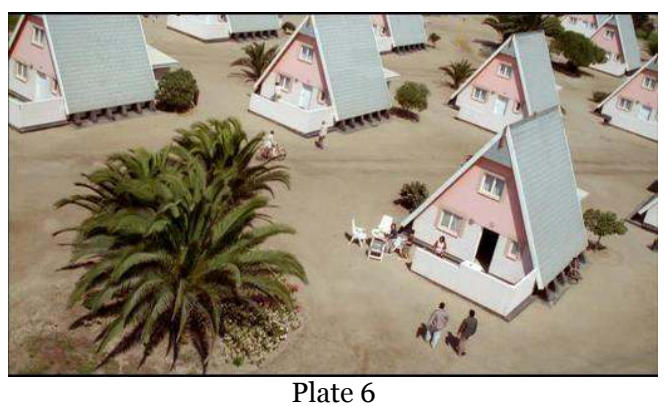

Such an equation between oral orders and visual control indirectly presents the encouraged addiction to TV series as a form of surveillance, a view of the modern ways of control that is confirmed by subsequent appearances of "Wonkers" in the 2009 Prisoner. One of them takes place later in episode 2, when Number 6 watches a moment in "Wonkers" which sounds strangely similar to his situation, as it is mostly about the impossibility of escaping a place.

MALE CHARACTER IN "WONKERS". Life is short.

FEMALE CHARACTER IN “WONKERS”. It's the same thing. Day in, day out. It's like we can never escape... 
A first level of reading is that Number 6 is provided, through his television set, with programmes fitted to his present concerns, very much the way Internet surveillance works ${ }^{11}$. Another level of reading is that "Wonkers", by putting the right ideas into the Villager's heads, acts as an instrument of power. In both cases, however, the way television fits into the surveillance pattern appears to be different from that found in the original version. Whereas the television set was presented to act as a surveillance apparatus, fictional TV programmes are now shown to participate in surveillance processes, a change made so radical in the 2009 version that it leads, by gradual stages, to the revelation of the actual location and nature of the Village in the last two episodes.

The ending of episode 2 links the series and the series-withinthe-series in a slightly different way from the other appearances of "Wonkers" in the 2009 Prisoner. Number 6, who has come to Number 16's house in order to tell his family that his alleged brother just died, finds his wife and children gathered around the television set for the daily ceremony of watching the addictive programme. The specific sequence they are watching shows the characters in "Wonkers", men and women alike, slapping each other in the face, which raises laughter among the audience. A close-up shot of Number 2 laughing out loud is then inserted, followed by a shot revealing that his hilarity is also a reaction to "Wonkers". In this shot, a transparent TV set displaying the show-within-the-show can be seen in the foreground. Because the screen is translucent, it superimposes pictures from "Wonkers" on pictures from The Prisoner, and enables the spectators to make out Number 2 sitting in the background (see Plate 7).

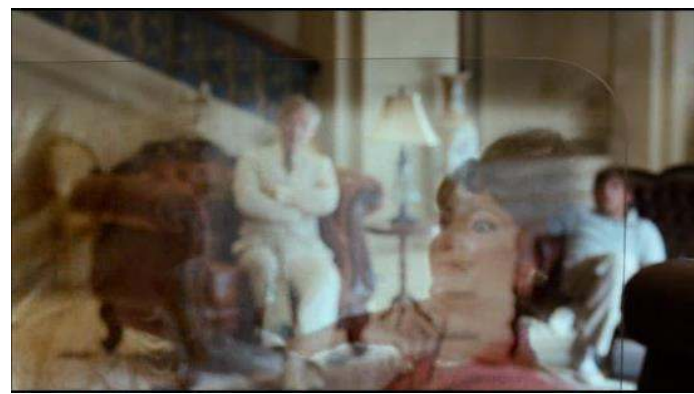

Plate 7

\begin{abstract}
${ }^{11}$ For a comprehensive study of the notion, see sections 8.2 and 8.3 in Hervé Chamley's Geosciences, Environment, and Man, which bear the titles "From Surveillance to Dataveillance: The Rise of the Electronic Web" and "The Development of Internet Surveillance". Hervé Chamley, Geosciences, Environment, and Man, Amsterdam, Elsevier, 2003, p. 141-148.
\end{abstract}


Similarly, the regular insertion of shots of Number 2 and Number 16's family laughing at "Wonkers" in the sequence creates a disturbing feeling: those reaction shots, because they are scattered throughout a sequence that combines shots showing a TV set on which "Wonkers" is displayed and shots of Number 6 announcing Number 16's death, gives the impression that the sad news makes the characters laugh. Generating confusion as to the cause of their reaction thus presents them as indiscriminate spectators, who are simultaneously responding to events occurring in the diegetic world of The Prisoner and to events taking place in the series within this world. In the eyes of the diegetic spectators, therefore, the series and the series-within-the-series can be seen to merge. This equation is further constructed by Number 2's comment, "none of us can choose our family", which applies to "Wonkers" but more interestingly sheds light on the series itself, since episode 2 as a whole shows Number 2 trying to cast Number 6 as Number 16's brother.

The presentation of life in the Village as life within a TV show of the "Wonkers" type, even though it is conveyed as soon as the very first episodes through a suburban landscape and idyllic atmosphere extremely reminiscent of The Truman Show (Peter Weir, 1998), becomes more explicit as Number 6 is getting closer to discovering the nature of the gilded cage entrapping him. Elements pointing to the final revelation, however, are scattered among all six episodes of the series. A particularly unequivocal description of this utopian world - it is both nowhere and apparently perfect - as a "Wonkers" lookalike or by-product is to be found as early as episode 2, during one of Number 6's obligatory visits to the Village shrink (who turns out, like many other Village inhabitants, and like Number 6 himself in episode 5 , to have an inseparable twin). In the course of the treatment, Number 6 suddenly takes the shrink aback by coming out with a reply that sounds like a synopsis of a "Wonkers" episode: "765 is in love with 23-30. 23-56 is pregnant to 46-5. Now, 913 had an affair with 23-30, so 765 is jealous of $23-30 . . . "$. Number 6 thus exposes what Number 2's henchmen in the Village are trying to make him do as extremely predictable because directly imitated from the mushy TV programme. His superiority over his manipulators at this specific moment is expressed again when he triumphantly concludes, addressing the psychiatrist: "I see your fear, 70. I've been watching you", a line which describes the shrink as a TV series flat character, but which also literally debunks the Village as a TV production.

Moreover, the presentation of the Village as a TV series set appears in the structure of The Prisoner episodes, which follow a recurrent storyline in which Number 2 tries to impose a part on Number 6. In episode 1, Michael enters the Village, where he is cast as Number 6 . From then on, he is only allowed to become Michael again 
in the New York City sequences edited in parallel with the Village scenes. Those sequences, even though they look like flashbacks, are later revealed to occur synchronously with those set in the Village. In episode 2, he is made to play the part of Number 16's brother. In episode 3, Number 6, still against his will, is cast as a surveillance teacher and as an undercover agent ${ }^{12}$. In episode 4, Number 6 is made to play a part in a planned love story that seems directly out of "Wonkers", which almost ends up in his getting married to 4-15, the Village avatar of a lady he has just met in one of the parallel sequences set in New York. In this episode, it thus gradually appears that each of the characters seen in the New York sequences has a double who simultaneously leads a parallel life in the Village, as Number $\mathrm{x}$ or $\mathrm{y}$. In episode 5, after the appearance of Number 6 and Number 2's doppelgängers in the Village, 2 attempts to present 6 as the villain of the piece. In episode 6 , finally, Number 2 manages to win his game of chess against 6 by casting him as "the one", i.e. as both the new Village head and the new Summakor manager.

Number 2 obtains this victory by fitting 6 into the plot he has devised: 6 will be acclaimed as the new Number 2 by the Villagers ${ }^{13}$. But this final writing of the character's destiny, which is consistent with the reading of life in the Village as life in a scripted TV show, is accompanied by the revelation of the key to the mystery, which is in fact the disclosure of what, rather than where, the Village really is. In the final moments of episodes 5 and 6 , the nature of Michael/Number 6's job at Summakor is unveiled. This revelation connects surveillance with TV series: Summakor organises panoptic watching of people for the sake of detecting those in trouble. The company subsequently provides the elect with a better existence in the Village by putting a utopian second life into their heads. This is exemplified in one of the final shots in the series, in which Michael,

${ }^{12}$ One of the other aspects of contemporary surveillance exploited by the series is related to the way it sometimes shows Number 2 centralising information collected by several watching entities rather than sitting in a control room providing him with total coverage of the Village. Episode 3 as a whole is the main instance of this complementary perspective, because it presents surveillance as effected by all the citizens on all the citizens, with Number 2 at the head, a perfect illustration of the fact that the new Village, despite its mainly synoptic feature, also evinces catoptic qualities - the catopticon being a nonhierarchical pattern in which everyone watches everyone: "Dans Voir et pouvoir, qui nous surveille?, Le Pommier, 2009, Jean-Gabriel Ganascia propose une expression similaire, le 'catopticon', pour designer une architecture de 'sous-veillance' dans laquelle tout le monde surveille tout le monde, sans aucune hiérarchie." "In Voir et pouvoir, qui nous surveille?, Le Pommier, 2009, Jean-Gabriel Ganascia coins a [...] phrase, the 'catopticon', to describe a sub-veillance architecture in which everyone watches everyone, with no hierarchy." Renaud Francou, Daniel Kaplan and Charles Népote, Informatique, Libertés, Identités, Limoges: FYP Editions, 2010, p. 139. My translation.

${ }_{13}$ This scene takes advantage of Ian McKellen's fame as Shakespearian actor to suggest 2 is an inverted version of Richard III, as he manipulates the crowd into acclaiming 6 as the new ruler, while Gloucester organised plebiscite as King for himself. 
now Summakor's new managing director, gazes at a surveillance screen (see Plate 8). The picture he watches is split into several frames, on which unknown people's faces appear. In one of the pictures, however, Michael/6 is sitting on a sand dune, gazing at the horizon, and apparently enjoying life in the Village (see Plate 9). The same picture reappears full-screen in the show's ultimate moments (see Plate 10), proving that the surveillance screens at Summakor display the same pictures as The Prisoner is made of. The shot thus demonstrates that the Village does not merely resemble a TV show: it is a TV show.
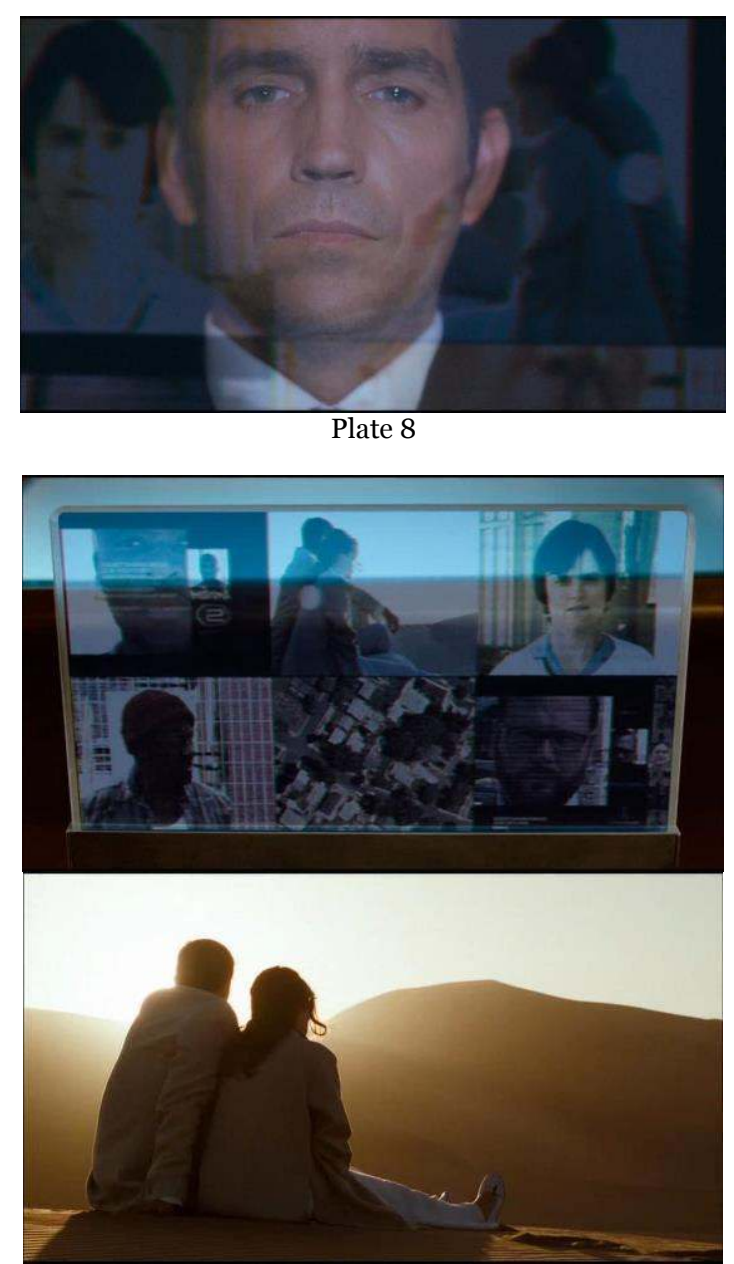

Plates 9 and 10 
Michael thought his task at Summakor was to keep people under surveillance by watching a screen: it was in fact to literally turn their lives into a TV series. As exemplified by one of Michael's earlier comments on his occupation in episode 2, Summakor gives surveillance a new purpose. Describing his job at Summakor, Michael had declared he had noticed the people he was watching were changing. In episode 6 , the disclosure of the Village's nature suggests that this change was not a spontaneous alteration: the transformation was just a sign that reality was being fictionalised under his eyes. At Summakor, a control monitor is simultaneously a TV screen, on which characters are seen playing parts, and literally "disappear[ing] in the televisualisation of their lives", to take up a phrase by Hille Koskela ${ }^{14}$.

Because it shows that surveillance has evolved from watching people into watching fake images of characters living in an imaginary world, the 2009 Prisoner can be considered a postmodern version of the original. Whereas the 1967 programme used a mise-en-abyme pattern to present television as a surveillance tool, the new version uses a similar starting point to draw different conclusions, in keeping with the state of surveillance at the beginning of the $21^{\text {st }}$ century. At Summakor, surveillance footage is no longer a mere capture of reality, but the creation of an alternative - supposedly better - world, to be thrust into people's heads. Through this science-fictional hypothesis, surveillance is described to fit into a manipulation pattern rather than into a mere spying pattern. Rather than surveillance monitors, the show's ending presents "remote-control screens", as it were, on which people's lives are not just caught, but directed. The adaptations from the original show, therefore, should not be considered to have been effected only in order to suit contemporary audience tastes. The 2009 Prisoner, rather, re-assesses the place of television in an overall surveillance scheme. Instead of merely relocating the Village, it remediates the place by showing it to be not only under the gaze of the mass media, but mediatically produced. Through the use of a TVseries-within-the-series and the utilisation of surveillance as its bedrock, the new version argues that the evolution of society has remediated TV into a newly powerful tool, which is able to fashion people's lives. In keeping with recent analyses of TV's inherent falsification of reality ${ }^{15}$, it also demonstrates that surveillance produces

14 Hille Koskela, “'Cam Era' - The Contemporary Urban Panopticon,” Surveillance \& Society, Vol. 1, No. 3, 2009, p. 305 [p. 292-313].

${ }_{15}$ As Sean Cubitt states, commenting on an essay about "neo-TV" by Umberto Eco, "Neo-TV brings in a falsification of reality such that it will conform not to a known ideology with roots in the real world, but only to the fictionalisations inherent in the medium. The only truth of the media is that they stage reality to fit their requirements." Sean Cubitt, Simulation and Social Theory, London, Sage, 2001, p. 72. 
a generalised fictionalisation of life. At times when Facebook delivers its users with daily episodes from people's real existences, surveillance may actually be turning reality into a TV series.

\section{Bibliography}

Chamley Hervé, Geosciences, Environment, and Man, Amsterdam, Elsevier, 2003.

CuBITT Sean, Simulation and Social Theory, London, Sage, 2001.

FEUER Jane, Seeing Through the Eighties: Television and Reaganism, Durham, Duke University Press, 1995.

Francou Renaud, Daniel KAPLAN and Charles NePote, Informatique, Libertés, Identités, Limoges, FYP Editions, 2010.

Ganascia Jean-Gabriel, Voir et pouvoir, qui nous surveille? Paris, Le Pommier, 2009.

GAUdREAUlT André and François JosT, Le Récit cinématographique, Paris, Nathan, 1990.

KAPSIS Robert E., Hitchcock: The Making of a Reputation, Chicago, University of Chicago Press, 1992.

Koskela Hille, “Cam Era' - The Contemporary Urban Panopticon”, Surveillance \& Society, Vol. 1, No. 3, 2009.

LYON David, Surveillance Studies: An Overview, Cambridge, UK, Polity, 2007.

MATHIESEN Thomas, “The Viewer Society: Michel Foucault's 'Panopticon' Revisited”, Theoretical Criminology, Vol. 1, No. 2, 1997. 